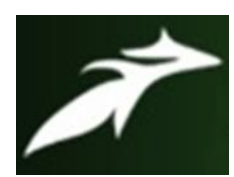

Ngukato K Yepthomi et al, International Journal of Advances in Agricultural Science \& Technology,

Vol.8 Issue.11, November-2021, pg. 20-27

ISSN: 2348-1358

Impact Factor: 6.057

NAAS Rating: 3.77

\title{
Perception of Shifting Cultivation Practicing Farmers towards Soil and its Nutrient Loss in Zunheboto District of Nagaland
}

\author{
Ngukato K Yepthomi*; Dr. Syed H Mazhar**; Dr. Dipak Kumar Bose*** \\ Department of Agricultural Extension and Communication, Sam Higginbottom University of Agriculture, \\ Technology \& Sciences, Prayagraj, 211007 (U.P.) India \\ Research Scholar* E-mail: nkyeptho@gmail.com \\ Professor** E-mail: syed.mazhar@ shiats.edu.in \\ Professor*** \\ DOI: 10.47856/ijaast.2021.v08i11.003
}

\begin{abstract}
The present study was conducted in the Zunheboto district of Nagaland. Zunheboto is bordered by Mokokchung district in the east, Kohima district in the south and Wokha district in the west. Out of total twelve districts in Nagaland, Zunheboto district is selected for the study. Majority of the respondents were from middle age group, educated up to literate, middle caste group from the joint family, having large family size. Most of the respondents were from small size of land holding, having medium group of annual income, majority of the respondents were from medium social participation. The findings of the study indicated that majority of respondents had adequate knowledge regarding impacts on complete forest loss, impacts on diverse land use system, bad impact of burned land on health of people and burning practice negatively impacted the biochemical processes of soils. Correlation coefficient showed that variables viz.., annual income, Land holding, social participation, extension contact were positively and significantly related with perception of respondents towards shifting cultivation practices.
\end{abstract}

Keywords: Shifting cultivation, Knowledge, Perception, Zunheboto.

\section{INTRODUCTION}

Shifting cultivation or Jhum cultivation is the oldest cultivation system practiced throughout the tropics and subtropics (zones of high rainfall, moderate temperature, and steep slopes) dating back to the Neolithic Period (13000-3000 BC). Shifting cultivation could be said to have evolved as a response to special physiographic characters of the land, the economy and socio-cultural traditions of the cultivators practicing it. 


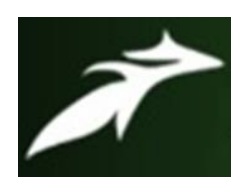

Ngukato K Yepthomi et al, International Journal of Advances in Agricultural Science \& Technology, Vol.8 Issue.11, November-2021, pg. 20-27

ISSN: 2348-1358

Impact Factor: 6.057

NAAS Rating: 3.77

Shifting cultivation systems encompass a remarkably diverse range of land use practices developed and changed over time by farmers in various social, ecological, economic, and political settings. Shifting cultivation systems are generally productive, make efficient use of resources, and have supported large populations. It is recognized that shifting cultivation is key to the livelihoods of many ethnic, indigenous and tribal groups in the tropical and sub-tropical highlands of Asia and Africa as well as Latin America. It is also one of the most complex and multifaceted forms of traditional agro forestry practice in the world reflecting a robust traditional ecological knowledge. It has evolved as a traditional practice and is an institutionalized resource management mechanism ensuring ecological security and food security thus providing a social safety net for local communities (Andersen et al., 2008).

The people of north-east India practice Jhum cultivation on hill slopes. Jhum cultivation contributes $85 \%$ of the total cultivation in north-east India. Population explosion and emergence of new generation of youth cultivators encouraged increasing demand for cultivable land which resulted reduction of the cycle of cultivation from 25-30 years to 2-3 years due to the abandoning and re-occupying of fallow land frequently. Fallow cycle of 2030 years prevalent during earlier period, helps the land to return to its natural condition after the anthropogenic disturbances. But, due to reduction of cycle to 2-3 years, the resilience of ecosystem is interrupted and the quality of the land is get worsening day by day. Its critiques call it as an inefficient and wasteful form of agriculture, while others see this as diversified livelihood system that ensures sustenance along with conservation of associated rich cultural heritage. The shortening Jhum cycle (the intervening period between fallowing and returning to the same spot for cultivation) from traditional 10 years or more to 4-5 years on an average now is indeed a matter of concern. This is seriously affecting the local livelihoods and environmental security in many pockets of the region. 


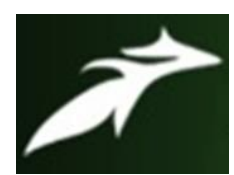

Ngukato K Yepthomi et al, International Journal of Advances in Agricultural Science \& Technology, Vol.8 Issue.11, November-2021, pg. 20-27

ISSN: 2348-1358

Impact Factor: 6.057

NAAS Rating: 3.77

\section{MATERIALS AND METHODS}

The present study was conducted in the Zunheboto district of Nagaland. Zunheboto is bordered by Mokokchung district in the east, Kohima district in the south and Wokha district in the west. Out of total twelve districts in Nagaland, Zunheboto district is selected for the study. 3 (three) block will be taken up for the survey.viz, Akuluto, Zunheboto Sadar and Satakha From each selected block, 2(two) villages will be included in the survey as sample villages. Thus, the sample survey will cover 6 (six) villages. From each selected village, 10\% of the household will be selected which will include both progressive and non-progressive farmers, thus the total sample comprised of 120 respondents.

\section{RESULT AND DISCUSSION}

3.1: Distribution of respondents according to personal, socio-economic, and communicational characteristics

Majority of respondents belonged to the age group of 38 to 53 years. This group alone constitutes 46.66 per cent of the total sample. Majority of respondents belonged to the literate (43.34\%) and about 37.50 percent respondents have 1 to 2 ha. land. Maximum percentage of the respondents (42.50\%) were found in annual income range of Rs. 40000 to 80000. majority of respondents i.e. 70.00 per cent were from large families and 63.33 per cent families were joint in their compassion.

\section{2: Distribution of respondents on the basis of level of knowledge about effects of shifting cultivation practices on soil and its nutrients}

Majority of respondents 60.83 per cent fell in medium level knowledge group whereas 17.50 per cent respondents were observed in low level knowledge group and remaining 21.67 per cent respondents possessed high level of knowledge about effects of shifting cultivation practices on soil and its nutrients. The respondents were categorized into three groups based on equal interval method as presented in Table 3.1. 


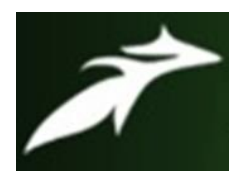

Ngukato K Yepthomi et al, International Journal of Advances in Agricultural Science \& Technology, Vol.8 Issue.11, November-2021, pg. 20-27

Table 3.1: Distribution of respondents on the basis of level of knowledge about effects of shifting cultivation practices on soil and its nutrients.

\begin{tabular}{|c|c|c|c|}
\hline Knowledge level & Knowledge score & Frequency & Total percent \\
\hline Low & Below 70 & 21 & 17.50 \\
\hline Medium & 70 to 80 & 73 & 60.83 \\
\hline High & Above 80 & 26 & 21.67 \\
\hline Total & & $\mathbf{1 2 0}$ & $\mathbf{1 0 0 . 0 0}$ \\
\hline
\end{tabular}

3.3: Extent of knowledge of farmers about effects of shifting cultivation practices on soil and its nutrients.

The knowledge of the respondents was measured into 14 major practices which have been given in the table 3.2

Table 3.2: Extent of knowledge of farmers about effects of shifting cultivation practices on soil and its nutrients.

$\mathbf{N}=120$

\begin{tabular}{|c|l|c|c|}
\hline S. No. & \multicolumn{1}{|c|}{ Aspects/ Practices } & \multicolumn{2}{l|}{ Total respondents } \\
\cline { 3 - 4 } & & MPS & RANK \\
\hline 1. & $\begin{array}{l}\text { Deforestation in shifting cultivation practices } \\
\text { have resulted in tremendous soil loss }\end{array}$ & 62.10 & XI \\
\hline 2. & Soil erosion occur due to shifting cultivation & 72.17 & VII \\
\hline 3. & Bad impact of burned land on health of people & 75.98 & III \\
\hline 4. & $\begin{array}{l}\text { Continuous shifting cultivation impacts on } \\
\text { complete forest loss }\end{array}$ & 88.23 & I \\
\hline 5. & $\begin{array}{l}\text { Burning practice negatively impacted the } \\
\text { biochemical processes of soils }\end{array}$ & 74.78 & IV \\
\hline 6 & $\begin{array}{l}\text { Continuous shifting cultivation impacts to loss } \\
\text { of biodiversity }\end{array}$ & 74.34 & V \\
\hline
\end{tabular}




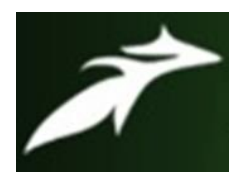

Ngukato K Yepthomi et al, International Journal of Advances in Agricultural Science \& Technology, Vol.8 Issue.11, November-2021, pg. 20-27

ISSN: 2348-1358

Impact Factor: 6.057

NAAS Rating: 3.77

\begin{tabular}{|c|l|c|c|}
\hline 7. & $\begin{array}{l}\text { Continuous shifting cultivation impacts change } \\
\text { in climate }\end{array}$ & 71.28 & VIII \\
\hline 8. & $\begin{array}{l}\text { Shifting cultivation impacts on degradation of } \\
\text { watershed }\end{array}$ & 61.60 & XII \\
\hline 9. & $\begin{array}{l}\text { Continuous shifting cultivation leads forest } \\
\text { product impoverishment }\end{array}$ & 62.75 & X \\
\hline 10. & $\begin{array}{l}\text { Continuous shifting cultivation impacts on } \\
\text { extension of diverse forest species }\end{array}$ & 66.12 & IX \\
\hline 11. & $\begin{array}{l}\text { Shifting cultivation impacts on diverse land use } \\
\text { system }\end{array}$ & 86.32 & II \\
\hline 12. & $\begin{array}{l}\text { Shifting cultivation impacts on decline of soil } \\
\text { fertility and its productivity }\end{array}$ & 73.86 & VI \\
\hline 13. & $\begin{array}{l}\text { Shifting agricultural practices it results in felling } \\
\text { of vegetation }\end{array}$ & 58.10 & XIV \\
\hline 14. & $\begin{array}{l}\text { Burning speeds up the course of the impact of } \\
\text { global warming as a direct effect }\end{array}$ & 60.75 & XIII \\
\hline
\end{tabular}

\section{MPS= Mean Percent Score}

\section{4: Distribution of respondents on the basis of their perception towards shifting cultivation practices}

It is indicated from the table 3.3 that majority of respondents 57.50 per cent had clear perception about shifting cultivation practices while about 28.33 per cent of respondents had no perception about shifting cultivation practices. About 14.17 per cent of respondents had partial perception about the shifting cultivation practices. 


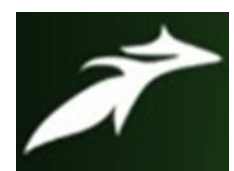

Ngukato K Yepthomi et al, International Journal of Advances in Agricultural Science \& Technology, Vol.8 Issue.11, November-2021, pg. 20-27

ISSN: 2348-1358

Impact Factor: 6.057

NAAS Rating: 3.77

Table 3.3: Distribution of respondents on the basis of their perception towards shifting cultivation practices

\begin{tabular}{|c|c|c|c|}
\hline S. No. & Perception level & No. of respondent & Total percent \\
\hline 1. & Clear perception & 69 & 57.50 \\
\hline 2. & Partial perception & 17 & 14.17 \\
\hline 3. & No perception & 34 & 28.33 \\
\hline & Total & $\mathbf{1 2 0}$ & $\mathbf{1 0 0 . 0 0}$ \\
\hline
\end{tabular}

\section{Perception of the respondents towards shifting cultivation practices}

Individual aspect wise perception was worked out. For this, mean per cent score of each practice was calculated. The results are presented in Table 3.4.

It was found that the overall perception of Negative impact on environment was ranked first with MPS 79.10 likewise, Complete forest loss with MPS 78.83, Forest area reduction with MPS 76.45, Soil nutrients loss is caused by natural process and human activity with MPS 74.22 were ranked second, third and fourth, respectively in perception by the respondents. A high perception was found in these practices because these practices do not require much specialized skills by farmers.

It was found that some respondents had less perception regarding Extension of diverse forest species with MPS 42.65, downstream effects with MPS 39.40 and Enormous loss of topsoil and soil nutrients with MPS 35.00 and they were ranked $8^{\text {th }}, 9^{\text {th }}$ and $10^{\text {th }}$, respectively. It was observed that it may be due to lack of knowledge about new technology may causes less perception of these recommended practices by the respondents.

Table 3.4: Perception of the respondents towards shifting cultivation practices

\begin{tabular}{|c|c|c|c||}
\hline S. No & practice & MPS & Rank \\
\hline 1. & Deteriorated health and reduced the fertility of soil & 68.01 & VI \\
\hline 2. & Enormous loss of topsoil and soil nutrients & 35.00 & $\mathrm{X}$ \\
\hline 3. & Downstream effects & 39.40 & $\mathrm{IX}$ \\
\hline 4. & Negative impact on environment & 79.10 & $\mathrm{I}$ \\
\hline
\end{tabular}




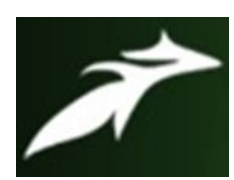

Ngukato K Yepthomi et al, International Journal of Advances in Agricultural Science \& Technology, Vol.8 Issue.11, November-2021, pg. 20-27

ISSN: 2348-1358

Impact Factor: 6.057

NAAS Rating: 3.77

\begin{tabular}{|c|l|c|c||}
\hline 5. & Forest area reduction & 76.45 & III \\
\hline 6. & $\begin{array}{l}\text { Complete forest loss Deteriorated health and reduced the } \\
\text { fertility of soil }\end{array}$ & 78.83 & II \\
\hline 7. & Forest product impoverishment & 67.36 & VII \\
\hline 8. & Extension of diverse forest species & 42.65 & VIII \\
\hline 9. & $\begin{array}{l}\text { Soil nutrients loss is caused by natural process and human } \\
\text { activity }\end{array}$ & 74.22 & IV \\
\hline 10. & Nutrients loss might affect agriculture productivity & 74.12 & V \\
\hline
\end{tabular}

\section{5: Relationship between profile of respondents and variables with perception}

The coefficient of correlation was worked out to know the relationship of the independent variables with the perception of respondents towards shifting cultivation practices. The results were furnished in table 3.5.

It was evident from table no 3.5 that the results of correlation coefficient showed that variables viz.., annual income (0.801), Land holding (0.618), social participation (0.815), extension contact (0.934) were positively and significantly related with perception of respondents towards shifting cultivation practices. The variable like age (-0.786) and size of family (-0.281) were negatively and significantly related with perception of respondents towards shifting cultivation practices. The variables like education (0.317) and family type (0.258 ) was non significantly related with the perception of respondents.

Table 3.5: Relationship between profile of respondents and variables with perception

\begin{tabular}{|l|l|c|}
\hline S. No. & Independent variables & Correlation coefficient (r) \\
\hline 1. & Age & $-0.786^{* *}$ \\
\hline 2. & Education & $0.317 \mathrm{NS}$ \\
\hline 3. & Annual income & $0.801^{* *}$ \\
\hline 4. & Land holding & $0.618^{* *}$ \\
\hline 5. & Family size & $-0.281^{* *}$ \\
\hline
\end{tabular}




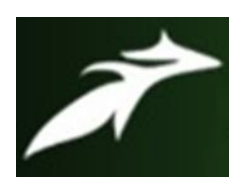

Ngukato K Yepthomi et al, International Journal of Advances in Agricultural Science \& Technology, Vol.8 Issue.11, November-2021, pg. 20-27

ISSN: 2348-1358

Impact Factor: 6.057

NAAS Rating: 3.77

\begin{tabular}{|l|l|c|}
\hline 6. & Family type & $-0.258 \mathrm{NS}$ \\
\hline 7. & Extension contacts & $0.934 * *$ \\
\hline 8. & Social participation & $0.815^{* *}$ \\
\hline
\end{tabular}

** Correlation is significant at the 0.05 level of probability NS= Non-significant

\section{CONCLUSION}

It was concluded that majority of the respondents were from middle age group, educated up to literate, middle caste group from the joint family, having large family size. Most of the respondents were from small size of land holding, having medium group of annual income, majority of the respondents were from medium social participation. The findings of the study indicated that majority of respondents had adequate knowledge regarding impacts on complete forest loss, impacts on diverse land use system, bad impact of burned land on health of people and burning practice negatively impacted the biochemical processes of soils. It was concluded that annual income, Land holding, social participation, extension contact were positively and significantly related with perception of respondents towards shifting cultivation practices.

\section{REFERENCES}

[1]. ANDERSEN, K. E., SOPHORN, S. AND THORNBERRY, F., 2008, Development of Sub-decree on Shifting Cultivation under Article 37 of the Forestry Law, Cambodia, International Labor Organisation.

[2]. Das S \& Das M (2014). Shifting Cultivation in Tripura: A Critical Analysis. Journal of Agriculture and Life Sciences, 1(1), (June), 48-54.

[3]. Maithani B.P. (2005). Shifting Cultivation in North-East India Policy Issues and Options. Published and printed by Krishna for Mittal Publications, Mohan Garden, New Delhi, India.

[4]. TIWARI, B. K., 2005, Shifting Agriculture in North-eastern India: Some insights in Spatiotemporal Pattern and Processes, Workshop on Shifting Agriculture, Environment Conservation and Sustainable Livelihood of Marginal Mountain Societies (Guwahati:NIRD). 